\title{
Contexto e voto: o impacto da reorganização da direita sobre a consistência ideológica do voto nas eleições de 2018
}

\author{
Mario Fuks ${ }^{1}$ ib \\ Pedro Henrique Marques $^{2}$ (D)
}

\begin{abstract}
Este artigo tem como objetivo avaliar o efeito da ideologia sobre o voto em Bolsonaro na eleição presidencial de 2018. Nosso argumento é que, após um longo período de ação discreta sobre o comportamento político dos brasileiros, os fatores ideológicos voltaram a ter relevância. A partir de uma perspectiva contextualista, apresentamos indícios de que a reorganização da direita no parlamento, nas ruas e nos meios de comunicação e a oferta de uma candidatura de extrema direita na competição eleitoral criaram condições favoráveis para o alinhamento, no eleitorado, entre a ideologia e a escolha eleitoral em 2018. Os dados revelam que o brasileiro está mais ideologicamente orientado e confirmam o impacto da ideologia sobre o voto.
\end{abstract}

Palavras-chave: ideologia; comportamento eleitoral; eleições 2018

\section{Introdução}

A discussão sobre a relação entre ideologia e comportamento eleitoral tem uma longa tradição na ciência política, que remonta aos estudos seminais da escola de Michigan (Campbell et al., 1960; Converse, 2006a). Segundo esses estudos, o partidarismo é, exceto para a minoria de eleitores mais escolarizados e interessados por política, um tipo de identificação predominantemente afetiva, sendo, no limite, desprovido de conteúdo ideológico. A maioria dos eleitores seriam, então, ideologicamente inconsistentes. Desde então, reinou um pessimismo a respeito da capacidade de o eleitorado se orientar na política a partir de referências ideológicas (Kinder, 2006; Kinder e Kalmoe, 2017), agravado no caso das novas democracias (Bustikova e Zechmeister, 2017).

No Brasil, diversos autores chegaram a conclusões semelhantes. Estudos desenvolvidos nas décadas de 1960, 1970 e 1980 (Cintra, 1968; Lamounier, 1980; Reis, 1978) mostraram a ausência de posições ideológicas em relação ao regime político na adesão das classes populares ao MDB. Estudos mais recentes têm identificado a compreensão

\footnotetext{
${ }^{1}$ Departamento de Ciência Política da Universidade Federal de Minas Gerais. Belo Horizonte (MG), Brasil. E-mail: <mariofuks@gmail.com>.

2 Departamento de Ciência Política da Universidade Federal de Minas Gerais. Belo Horizonte (MG), Brasil. E-mail: <pedrohenriquemarques91@gmail.com>.
} 
equivocada dos brasileiros sobre os significados dos termos esquerda e direita, incompreensão essa que aumenta à medida que diminui o nível de escolaridade (Carreirão, 2002; Almeida, 2007). Eles também têm apontado a ausência de conexão entre o autoposicionamento na escala ideológica e as preferências políticas do eleitorado (Oliveira e Turgeon, 2015) e entre ideologia e partidarismo (Borges e Vidigal, 2018; Samuels e Zucco Júnior, 2018).

Apesar desses desenvolvimentos, não há consenso a respeito da validade universal desses achados. Já na década de 1970, em resposta ao radicalismo cognitivista de The American voter (Campbell et al., 1960), Nie e Andersen (1974) argumentaram que a coesão do sistema de crenças políticas dos eleitores norte-americanos variava de acordo com o contexto social e político. Segundo os autores, o ambiente de intensas mobilizações sociais que varreram os EUA nos anos 1960 teria despertado, no eleitor, maior atenção à política e às disputas ideológicas, e levado, consequentemente, ao aumento de consistência ideológica. Desde então, parte da literatura ressalta como o contexto político, em especial, o grau de polarização entre as elites políticas, pode (ou não) favorecer uma maior consistência ideológica dos eleitores (Fiorina, Abrams e Pope, 2006; Fiorina e Abrams, 2008; Lachat, 2008; Levendusky, 2010; Abramowitz, 2010; Dalton, 2011; Ellis e Stimson, 2012; Singer, 2016).

No Brasil, o contexto político começa a ganhar espaço já nos estudos dos anos 1980 (Reis, 1988), aparecendo, posteriormente, nas discussões sobre os efeitos da redemocratização sobre a estruturação ideológica do comportamento dos eleitores brasileiros (Singer, 2000) e, de forma mais sistemática, nos estudos sobre voto e partidarismo pós2002 (Carreirão, 2007, 2008). Carreirão mostrou um forte declínio da associação entre ideologia e partidarismo (Carreirão, 2008) e entre ideologia e o voto (Carreirão, 2007) em 2006, quando comparado com 2002. O autor argumentou que esse enfraquecimento da relação entre ideologia e voto se deve à diluição das diferenças ideológicas entre os partidos na percepção dos eleitores. Isso teria ocorrido em função da continuidade da política econômica do PSDB no governo do PT e do envolvimento do PT em escândalos de corrupção. Em estudo posterior, Bonifácio, Casalecchi e Sandes-Freitas (2014) mostraram que esse enfraquecimento da relação entre ideologia e voto se acentuou em 2010.

No presente artigo, utilizando dados do Latin American Public Opinion Project (Lapop 2007, 2008, 2010, 2012, 2014, 2017, 2019) da Vanderbilt University, do Estudo Eleitoral Brasileiro (Eseb 2002, 2014, 2018) e do Datafolha (1989, 1993, 1999, 2000, 2003) argumentamos que, acompanhando a mudança do contexto político brasileiro, está em curso o crescimento da influência da ideologia sobre o comportamento político. Esse novo contexto tem como um dos seus principais componentes a reorganização da direita, processo mediante o qual a direita não apenas aumenta sua presença no parlamento e na sociedade, como também assume e reivindica sua identidade ideológica. Paralelamente e reforçando esse cenário, surge, na competição eleitoral, a oferta de uma alternativa que manifesta, 
enfaticamente e de forma reiterada, posições de direita, especialmente na área de segurança e dos costumes.

Nosso argumento, portanto, é que o declínio da associação entre ideologia e comportamento político identificado por Carreirão $(2007,2008)$ não só é interrompido como há uma clara inversão de rumo em 2018. Os dados analisados aqui mostram que, nesse novo contexto político, no qual os partidos e ativistas apresentam contornos ideológicos mais nítidos, o eleitor mostra maior consistência entre a sua posição ideológica, de um lado, e sua preferência partidária e seu voto, de outro. Esse novo contexto é o pano de fundo de "Ideologia e voto em 2018", na qual examinamos se a ideologia teve impacto sobre o voto em Bolsonaro. Os resultados confirmam a relevância da ideologia, mais especificamente do voto conservador, tanto no âmbito dos costumes como na área de segurança pública, em Jair Bolsonaro.

Este artigo se divide em duas seções, além da "Introdução" e das "Considerações finais". Em "Ideologia e contexto", revisamos a literatura que analisa a influência do contexto sobre a consistência ideológica do eleitorado e o voto. Concluímos essa primeira seção com considerações sobre mudanças recentes no contexto político brasileiro, com destaque para a reorganização da direita e a consequente polarização política. Analisamos também a associação desse novo contexto com a relação entre ideologia, partidarismo e voto dos brasileiros. Em "Ideologia e voto em 2018", como mencionado acima, testamos se a ideologia é relevante para explicar o voto em Jair Bolsonaro em 2018.

\section{Ideologia e contexto}

As obras seminais de Campbell et al. (1960) e de Converse (2006a) inauguraram a tradição cognitivista nos estudos sobre ideologia, baseada, exclusivamente, em atributos individuais. Essa tradição tem como fundamento a tese de que a maioria dos eleitores não dispõe de muitos recursos cognitivos e, portanto, é ideologicamente inconsistente.

Há, no entanto, estudos que, desde a década de 1970, desafiaram essa tradição a partir da consideração de fatores contextuais. Foi com base em argumentos de natureza contextual que Nie e Andersen (1974) explicaram o ganho de consistência ideológica após os anos 1950, época analisada por Converse (2006a). Como mostraram Nie e Andersen (1974), a maior saliência dos conflitos políticos da década de 1960, com a luta pelos direitos civis, a guerra do Vietnã e o movimento da contracultura, criou condições favoráveis para que o eleitor menos sofisticado associasse, de forma mais coerente, suas preferências políticas, ideológicas e partidárias.

Desde então, embora esse tipo de interpretação permaneça à sombra da tradição cognitivista, o argumento de que o grau de consistência ideológica do eleitorado é 
condicionado pelo contexto político ganhou espaço na literatura ${ }^{3}$ (Stimson, 1975; Nie e Rabjohn, 1979; Bafumi e Shapiro, 2009). Abramowitz (2010), por exemplo, apresenta evidências de que, estimulados pela polarização das elites, os eleitores americanos ficaram mais polarizados e consistentes ideologicamente. Seguindo na mesma direção, Hetherington (2001) argumenta que a polarização das elites contribuiu para que os eleitores percebessem as diferenças ideológicas entre os partidos e promoveu o partidarismo entre o público.

Reforçando a tese da influência do ambiente político sobre a consistência ideológica dos eleitores, estudos comparados têm apresentado evidências de que, em contextos polarizados, a ideologia importa mais na hora do voto (Levendusky, 2010; Lachat, 2008; Dalton, 2011; Singer, 2016). Lachat (2008), por exemplo, mostra que a influência da ideologia sobre o voto aumenta com a polarização do sistema político. Segundo o autor, isso ocorre porque, nesse contexto, os partidos apresentam um conjunto de posições políticas mais coerentes entre si e mais associadas a orientações ideológicas. Com isso, torna-se mais fácil para o eleitorado usar essas referências para descrever a si mesmos e reconhecer os partidos, além de associar com maior facilidade as suas preferências ideológicas com o voto (Levendusky, 2010). Na mesma linha, Dalton (2011) mostra que esse efeito é substantivo até mesmo para os eleitores menos sofisticados politicamente e não partidários, enquanto Singer (2016) observa o mesmo fenômeno em novas democracias.

No Brasil, o estudo da relação entre ideologia e voto também é, desde o início, orientado pelo pessimismo cognitivista, com foco na baixa consistência ideológica do eleitor (Reis, 1978; Lamounier, 1980; Carreirão, 2002). Mas isso não quer dizer que considerações de natureza contextual não estejam presentes. Esse tipo de consideração surge com muita naturalidade na primeira geração de estudos sobre o voto, devido a sua orientação sociológica (Cintra, 1968; Reis, 1978; Lamounier, 1980). Um dos eixos desses estudos é a relação entre a urbanização e industrialização (regiões com maior renda, escolaridade, infraestrutura) e o voto progressista e ideologicamente orientado (Castro, 1997).

Com o acúmulo de eleições em ambiente democrático e a disponibilidade de dados longitudinais, a relação entre contexto e ideologia pode hoje ser testada de forma mais sistemática. Assim, Carreirão $(2007,2008)$ identifica, em 2006, quando comparado com 2002, uma perda da associação entre ideologia e voto e uma diminuição das diferenças ideológicas entre os eleitores que tinham identificação com partidos que competiam no cenário eleitoral ${ }^{4}$. Segundo o autor, essa diminuição da diferença ideológica entre os eleitores partidários seria decorrente do declínio das diferenças ideológicas entre os partidos, propiciado por um movimento do PT que, após assumir a presidência da República, deu continuidade às políticas macroeconômicas do PSDB, governou com base em coalizões

\footnotetext{
3 O próprio Converse (2006b) reconheceu que, com o passar dos anos, os eleitores norte-americanos se tornaram mais ideológicos.

4 Samuels (2008) e Veiga (2007) também encontram mudança do perfil ideológico do petista entre 2002 e 2006. Segundo eles, embora o partido tenha conseguido expandir suas bases, incorporando segmentos mais pobres e menos escolarizados da população, o processo teria sido acompanhado pela saída daqueles segmentos mais ideológicos.
} 
heterogêneas ideologicamente e se envolveu em escândalos de corrupção, diluindo suas diferenças em relação a outros partidos. Esses elementos contextuais teriam, segundo o autor, contribuído para a redução do vínculo entre voto, partidarismo e ideologia.

Tal análise, é importante ressaltar, é congruente com estudos sobre o Legislativo brasileiro que apontam, nesse mesmo período, a diluição da importância da ideologia entre os parlamentares. Assim, para Zucco Júnior (2011), o cenário era, ao menos até a legislatura eleita em 2006, o seguinte: 1) a orientação ideológica dos congressistas importava menos que o seu pertencimento ou não à coalizão de governo; 2) os principais partidos do Congresso brasileiro deram uma guinada para o centro, especialmente os de esquerda; e 3) os parlamentares e partidos de direita não se assumiam publicamente como tal, traço já identificado pela literatura (Rodrigues, 1987; Pierucci, 1999; Power e Zucco Júnior, 2009) e denominado como síndrome da direita envergonhada, devido à associação entre a direita e o regime militar 5 .

Esse contexto está mudando. Se o cenário anterior era de diluição das diferenças ideológicas entre os partidos e concomitante diminuição da associação entre ideologia e comportamento eleitoral dos brasileiros, está em curso, hoje, um movimento no sentido contrário. O principal agente dessa mudança, a reorganização da direita, não só no parlamento como também na sociedade, reforça a distinção entre esquerda e direita na política e oferece ao eleitorado claros sinais das diferenças ideológicas entre as opções eleitorais, o que favorece o voto com maior consistência ideológica. Antes de avançarmos nos testes que nos permitirão medir o impacto da ideologia sobre o voto em 2018, vamos caracterizar melhor esse novo cenário.

\section{A reorganização da direita no Brasil}

Definir de forma precisa quando se inicia o processo recente de reorganização da direita no Brasil é uma tarefa complicada, se não impossível. Vários estudos apontam um ponto de inflexão a partir do início da década de 2010, quando as iniciativas da direita do espectro político começaram a reverter a tendência centrista que caracterizou a política brasileira pós-redemocratização. Essa nova onda de direita já permite afirmar que o fenômeno da direita envergonhada no país (Quadros e Madeira, 2018; Melo, Câmara e Santos, 2020; Rocha, 2018) ficou no passado.

Segundo Quadros e Madeira (2018), a longa permanência do PT na presidência, a reação a sua agenda de minorias e o distanciamento, no tempo, do regime autoritário criaram um contexto favorável à reinvenção da direita no Legislativo brasileiro. Estaria, portanto, surgindo uma nova direita brasileira, dessa vez não vinculada à herança da

\footnotetext{
5 Para uma breve demonstração da persistência do fenômeno, segundo Zucco Júnior (2011): enquanto 25\% dos deputados federais da legislatura eleita em 2006 se colocavam, numa escala ideológica, mais à esquerda de onde colocavam seus próprios partidos, apenas 13,5\% se colocavam mais à direita de onde colocavam os próprios partidos, além disso, surpreendentes $88 \%$ dos parlamentares entrevistados posicionaram-se mais à esquerda do que a nota média atribuída ao próprio partido pelos deputados de outros partidos.
} 
ditadura militar nem tampouco ligada aos partidos tradicionais de direita, com seu foco prioritário na aplicação de uma agenda econômica neoliberal, como nos anos 1990. Sua identidade estaria, prioritariamente, associada a posições conservadoras no campo dos costumes, como a oposição à união entre pessoas do mesmo sexo e à discussão das teorias de gênero nas escolas, e na área de segurança pública, como a defesa da redução da maioridade penal, da extensão do porte de armas, do endurecimento das penas e posições contrárias às políticas de descriminalização das drogas (Quadros e Madeira, 2018).

Em sintonia com essa linha de interpretação, Melo, Câmara e Santos (2020) apresentam evidências de um processo de polarização ideológica no Congresso Nacional. Analisando os dados do "Projeto Elites Parlamentares na América Latina" (PELA), relativos aos deputados das cinco principais legendas do país, cobrindo as quatro últimas legislaturas (entre 2003 e 2019), os autores mostram que, já nas duas últimas, os parlamentares se posicionaram mais à direita do que faziam anteriormente. Como colocam os autores, "a direita saiu do armário, o que, como seria de esperar, se refletiu na Câmara dos Deputados" (Melo, Câmara e Santos, 2020, p. 8).

Nesses últimos anos, a direita se reorganizou e se expressou não apenas na esfera das instituições políticas. Segundo Saad-Filho e Boito (2016), a partir de 2013, uma nova e fortalecida direita vem para a rua, trazendo uma agenda que, apesar de heterogênea, compartilha o antipetismo e o conservadorismo moral. Alonso (2017), ao analisar manifestações na cidade de São Paulo desde 2013 ao final do governo Temer, mostra a escalada de enfrentamento ideológico que ocorre quando uma série de novos e vigorosos grupos e organizações de direita (como MPL, Vem Pra Rua, Revoltados Online) exigem o impeachment da ex-presidenta Dilma Rousseff (PT) e manifestam apoio à operação LavaJato e à prisão do ex-presidente Lula (PT).

Avritzer (2017) propõe uma interpretação das mudanças que ocorreram no campo da participação com esse despertar da direita. Segundo sua interpretação, a partir de 2013 houve uma transformação profunda do padrão de participação política inaugurado com a Constituição Federal de 1988 e intensificado nos governos petistas, cuja marca seriam os fóruns de discussão de políticas públicas e espaços de deliberação compostos pelo governo e sociedade civil. Já o novo padrão seria marcado pelos protestos das classes médias, ligadas predominantemente a ideologias de direita. Como resultado dessa mudança, a esquerda teria perdido o monopólio do campo participativo no Brasil, agora polarizado.

Mas não é só na arena parlamentar e na rua que encontramos claros indícios da emergência e da afirmação de identidade de uma nova direita. Como observam Chaloub e Perlatto (2016, p. 26), houve, nos últimos anos, um "destaque cada vez mais significativo na esfera pública do país de uma nova fração de intelectuais, portadores de certo tipo de ideário claramente de direita". Na esteira desse processo, intelectuais como Olavo de Carvalho, Reinaldo Azevedo, Luiz Felipe Pondé, Rodrigo Constantino, Guilherme Fiuza, Marco Antônio Villa, Denis Rosenfield, Diogo Mainardi, entre outros, estariam "ganhando um espaço cada vez mais significativo no debate público do país" (Chaloub e Perlatto, 2016, p. 26). A 
proliferação de think-tanks liberais, a abertura do mercado editorial e a estrutura de comunicação da internet, entre outros fatores, criaram condições favoráveis para divulgação do pensamento desses ideólogos.

Em relação à internet, inclusive, vários autores têm ressaltado o enorme alcance atingido nas redes sociais pelas páginas, grupos e perfis de direita (Messenberg, 2017; Penteado e Lerner, 2018). Outros ainda têm ressaltado a importância crucial que a internet teve na formação de uma rede de novos ativistas de direita num período em que muitos, dada a enorme taxa de aprovação de Lula, ainda não se encontravam confortáveis para se assumir publicamente como de "direita" (Rocha, 2018). Um exemplo dessa presença digital são os canais de conteúdo de direita no Youtube, cujo volume de inscritos e visualizações seriam maiores que os de canais de esquerda ${ }^{6}$. Destaca-se também a facilidade com que alguns dos expoentes dessa nova direita transitam entre diferentes mídias, combinando a inserção e a exposição de ideias em blogs e perfis na web, mas também na mídia convencional impressa ou televisiva (Fernandes e Vieira, 2019).

Por fim, o aspecto desse contexto mais relevante para o presente artigo foi a alteração do padrão ideológico da competição presidencial. A competição, que até pouco tempo parecia se estruturar no nível federal em torno de dois partidos relativamente próximos no espectro ideológico - PT, de centro-esquerda, e PSDB, de centro-direita -, passou a incluir, em 2018, um candidato declaradamente de direita e ativo no combate à esquerda. Foi com uma campanha pautada por elogios ao período da ditadura militar brasileira, por posições conservadoras no campo dos costumes e da segurança pública e por ataques à esquerda que, pela primeira vez, um candidato de extrema direita chegou ao segundo turno das eleições brasileiras desde a eleição presidencial de 1989.

Nesse novo contexto político brasileiro, caracterizado pela ampla e constante disseminação de mensagens políticas ideologicamente estruturadas e por alternativas eleitorais polarizadas, os eleitores tenderiam a usar mais essas referências ideológicas (Levendusky, 2010) para formar as suas preferências partidárias e decidir o seu voto? Ou seja, teria esse novo contexto político contribuído para aumentar a consistência ideológica do eleitor? Não temos uma resposta definitiva para essa pergunta, mas na próxima subseção apresentamos evidências de que as mudanças na consistência ideológica do eleitor brasileiro acompanham essas alterações no contexto político. Assim, embora nossa análise não tenha como base um teste estatístico, as evidências que apresentamos da convergência entre o padrão de mudanças no contexto e a consistência ideológica estão de acordo com a previsão da teoria.

${ }^{6}$ Fonte: <https://www.monitordigital.org/2019/09/27/nota-tecnica-05/>. Acesso em: 30 set. 2019. 
Consistência ideológica do eleitorado brasileiro (1989-2019)

Seguindo as teorias que atribuem relevância ao contexto sobre a competência política do eleitor (Nie e Andersen, 1974; Stimson, 1975; Nie e Rabjohn, 1979; Bafumi e Shapiro, 2009; Abramowitz, 2010; Hetherington, 2001; Fiorina, Abrams e Pope, 2006; Fiorina e Abrams, 2008; Singer, 2016), esperamos que, convergente à campanha ideologicamente polarizada e à mobilização da direita nas redes, nas ruas e nas instituições políticas, tenha ocorrido um alinhamento entre ideologia e voto no Brasil, em 2018. Nesta subseção, apresentamos evidências preliminares de tal alinhamento, mostrando que um maior número de eleitores tem se posicionado na escala ideológica e que houve aumento da consistência entre, de um lado, o posicionamento na escala e, de outro, o partidarismo e o voto.

Nos Gráficos 1, 2 e 3, construídos com os dados do Lapop, Eseb e Datafolha, há fortes evidências do aumento dessa consistência. Neles, é possível identificar três períodos. O primeiro período (1989-2002) é marcado por associações modestas entre ideologia e comportamento eleitoral. O segundo período (2003-2014) é marcado pela diluição desse componente ideológico (Carreirão, 2007, 2008; Bonifácio, Casalecchi e Sandes-Freitas, 2014). Finalmente, no terceiro período (2015-2019), a ideologia adquire maior consistência e, com isso, os eleitores passam a se situar mais na escala esquerda-direita e a diferenciar ideologicamente os partidos e os candidatos?.

O Gráfico 1 revela exemplarmente esses períodos. Entre 1989 e 2003, há uma relativa estabilidade com predomínio da posição de centro, seguida pela de direita. Nesse mesmo período, as taxas de não resposta foram relativamente altas, inclusive superando, em vários pontos da série, os que se localizam na esquerda. Entre 2003 e 2014, as tendências do período anterior se acentuam, com um crescimento do percentual de indivíduos que se situam no centro, assim como dos que não se posicionam na escala ideológica. No sentido inverso, há um esvaziamento das posições de esquerda e de direita. A partir de 2012, porém, há um aumento nas taxas de autolocalização na escala, intensificado no período 2014-2019. Basta dizer que, em 2010, 24\% dos brasileiros não sabiam se localizar na escala ideológica; já em 2019 esse número despencou para 7,5\%. Ao mesmo tempo, aumentaram, progressivamente, as taxas de autolocalização nos polos da escala. A esquerda cai entre 2017 e 2019, mas, ainda assim, ela fica dez pontos percentuais acima de 2010. Por fim, entre 2017 e 2019, o número de cidadãos que se situam na direita aumenta de $21,47 \%$ para $31,6 \%$. Esse conjunto de dados mostra que, no período em que a política brasileira se estrutura mais em termos ideológicos, os eleitores encontram mais facilidade para se situar no espectro ideológico. Nesse sentido, eles confirmam os resultados de estudos que mostram que a polarização ideológica das elites facilita, para os eleitores, o

\footnotetext{
7 A caracterização do período que vai de 2010 a 2014 é mais controversa, pois, nele, como veremos nos Gráficos 1, 2 e 3, os eleitores começam a se posicionar mais na escala ideológica, embora as relações entre essas posições, o partidarismo e o voto permaneçam extremamente baixas e declinantes.
} 
reconhecimento dos termos "esquerda" e "direita" (Lachat, 2008), razão pela qual em países mais polarizados os eleitores tendem a se posicionar mais na escala (Zechmeister e Corral, 2013).

\section{Gráfico 1}

Autolocalização ideológica, 1989-2019 (\% da população de eleitores)

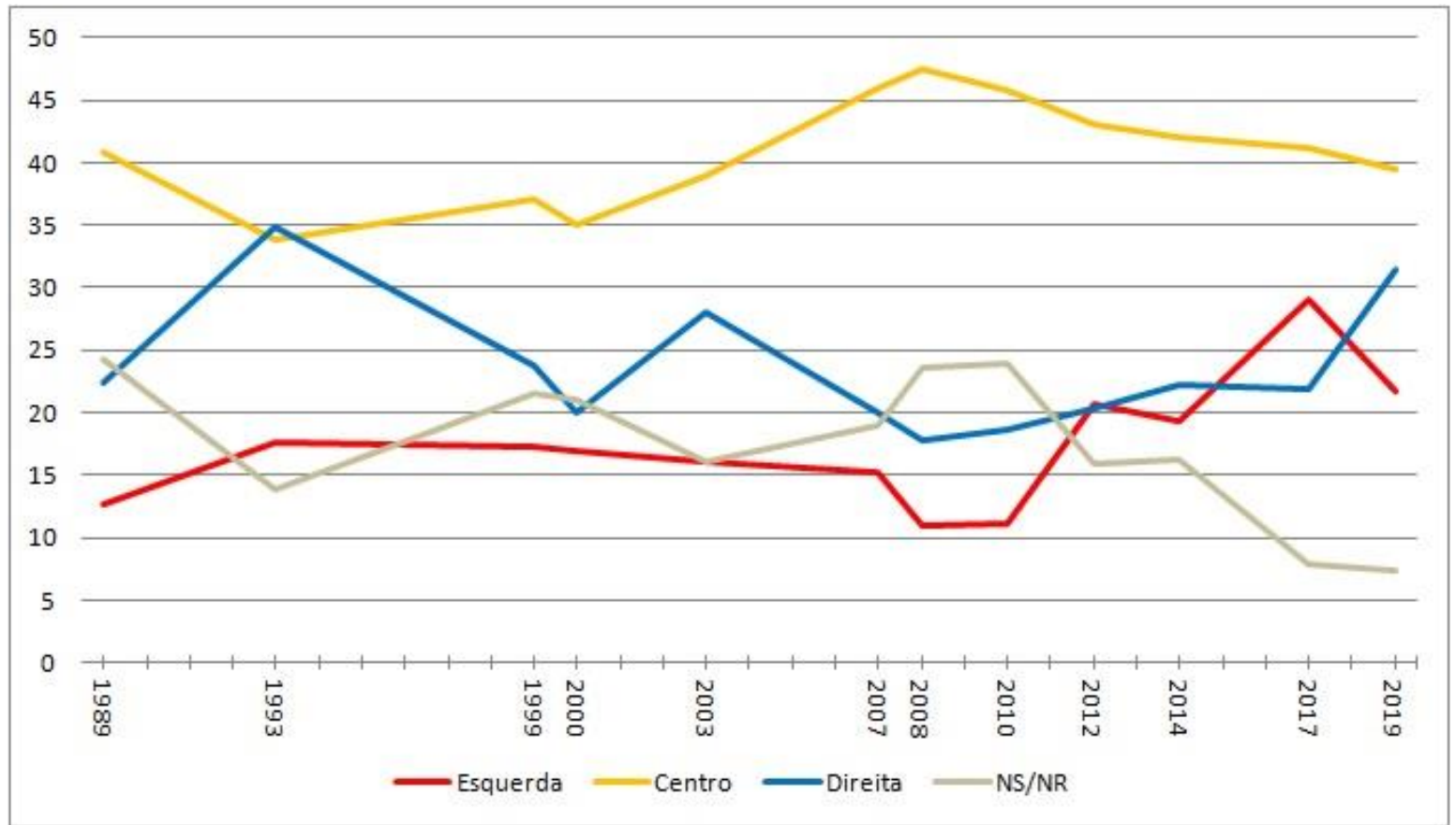

Fonte: Elaborado pelos autores com base no Datafolha 1989, 1993, 1999, 2000, $2003^{8}$ e no Lapop 2007, 2008, 2010, 2012, 2014, 2017, $2019^{9}$.

O Gráfico 2, com as medidas de correlação gamma entre a posição ideológica do entrevistado e a do partido com o qual ele se identifica, apresenta um padrão semelhante. Nele, podemos observar correlações moderadas entre as duas posições ideológicas até 2002; mas, como identificado por Carreirão (2007), há, após esse ano, um declínio substancial do componente ideológico do partidarismo. Já em 2019, porém, essa associação tornou-se muito mais forte, chegando a 0,64 alguns meses depois das eleições de 2018.

Os dados revelam, portanto, um aumento da capacidade do eleitor de organizar a política a partir de parâmetros ideológicos. Além de se identificar mais com uma determinada ideologia (inclusive, com crescimento nos polos), o eleitor brasileiro tende também a se aproximar da posição ideológica do seu partido preferido.

\footnotetext{
8 Codificação: 1-2 (esquerda), 3-5 (centro) e 6-7 (direita) para o Datafolha, com exceção de 1993. E 1-3 (esquerda), 4-7 (centro), 8-10 (direita) para Lapop e Datafolha 1993.

9 Os valores detalhados para cada ponto no gráfico se encontram na Tabela A1 dos Anexos.
} 


\section{Gráfico 2}

\section{Correlação gamma entre a autolocalização ideológica e a posição ideológica do partido preferido, 1989-2019}

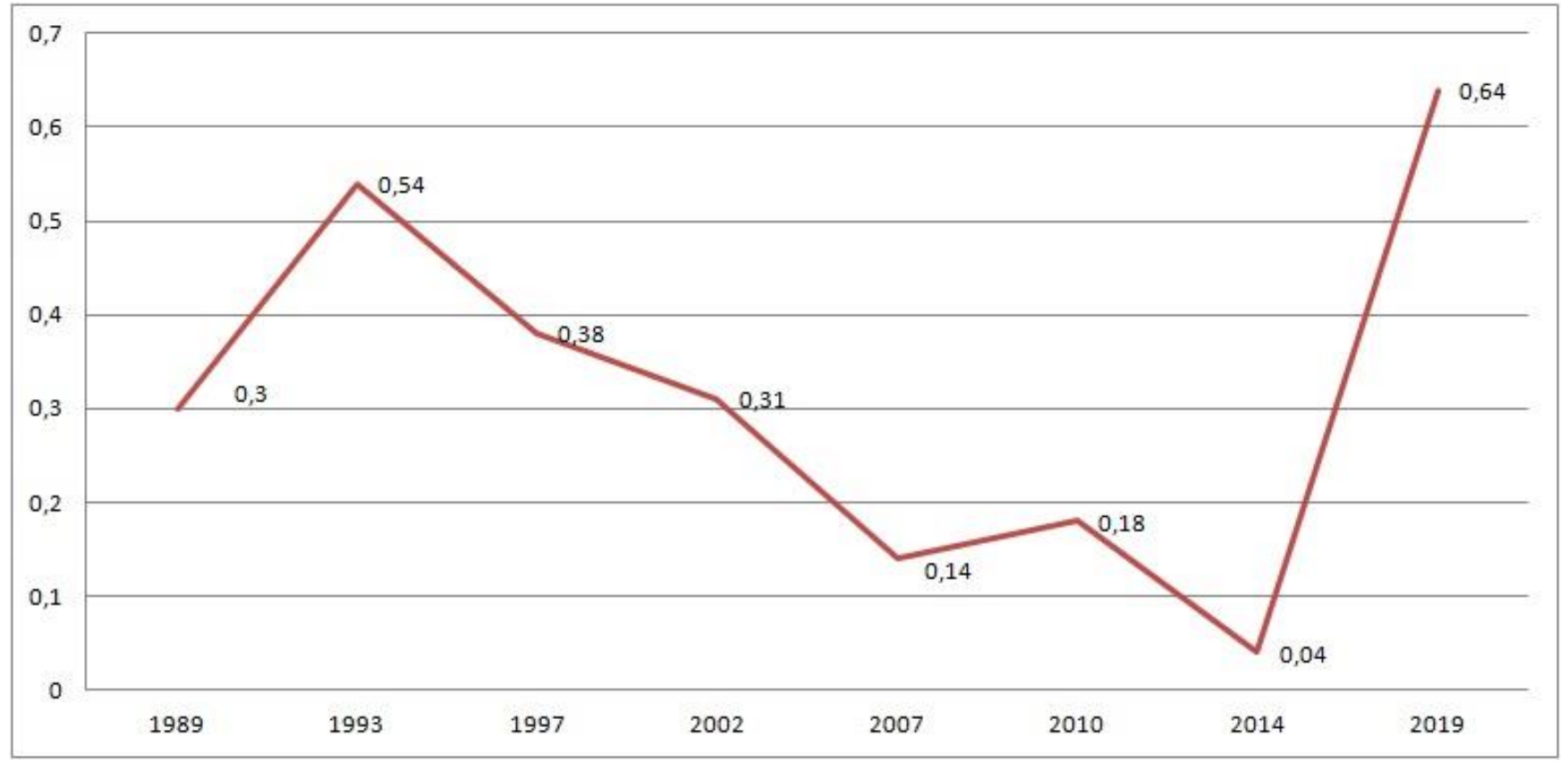

Fonte: Carreirão (2000) para 1989, 1994 e 1998. Eseb para 2002 e Lapop para 2007, 2010, 2014, $2019^{10}$.

O Gráfico 3 revela tendência semelhante. Entre 1989 e 2002, as correlações entre ideologia e voto ficam todas acima de 0,25, chegando a 0,39 em 1993. Como mostram Carreirão (2007) e Bonifácio, Casalecchi e Sandes-Freitas (2014), entre 2006 e 2014, há um contínuo declínio da associação entre ideologia e voto no país. Em 2018, ocorre uma mudança radical, com aumento expressivo do voto ideologicamente orientado, que pula de 0,08 para 0,38 .

\footnotetext{
10 A classificação ideológica dos partidos entre 2002 e 2018 foi efetuada com base numa variável construída a partir da média entre três indicadores de ideologia dos partidos (Tarouco e Madeira, 2015): a posição na escala de Wiesehomeier e Benoit (2007); a posição ideológica dos partidos segundo uma escala do survey com especialistas da ABCP, de 2010; e a média da autolocalização ideológica dos parlamentares por partido político, a partir da Pesquisa Legislativa Brasileira (PLB) de 2013. O resultado foi uma variável que vai de 2,11 até 9,9, cuja amplitude é de 7,79. Essa variável foi dividida por três para ter sua distribuição segmentada em três partes iguais. Assim, partidos que tiveram pontuações até 4.736667 foram categorizados como esquerda, entre 4.736668 e 7.356667, como centro, e depois disso como direita. A Tabela A2 dos Anexos detalha a classificação de cada partido. Para o ano de 2002, testamos uma classificação alternativa, seguindo a empregada por Carreirão (2000) para as eleições de 1998, com o PTB e o PSDB no centro e o PDT e o PV na esquerda, mas a alteração não foi substantiva. Para a classificação ideológica dos partidos entre 1989 e 1997, ver Carreirão (2000).
} 


\section{Gráfico 3}

\section{Correlação gamma entre voto no primeiro turno e autolocalização ideológica, 1989-2018}

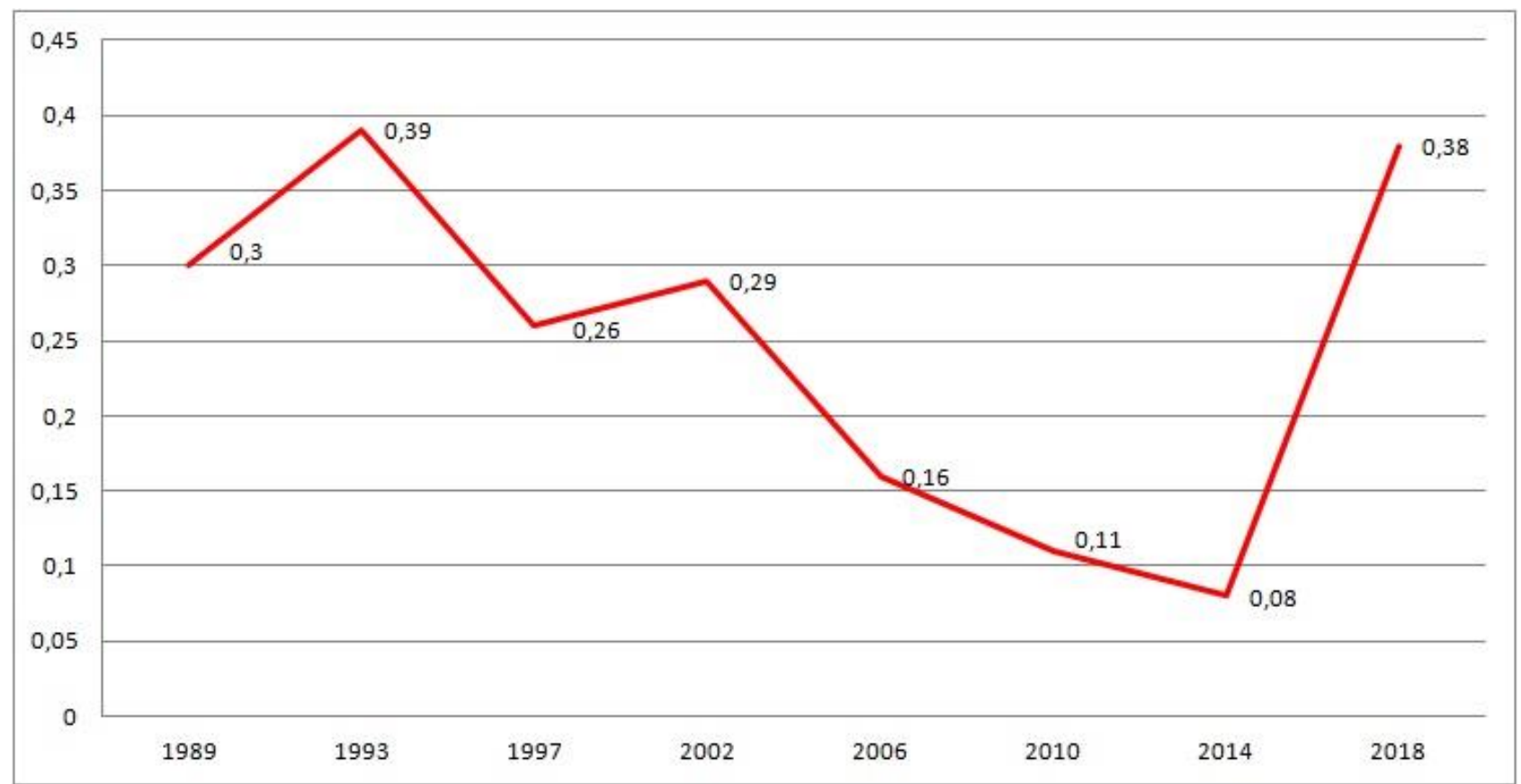

Fonte: Carreirão (2000) para 1989, 1993, 1997. Carreirão (2007) para 2002 e 2006. Bonifácio, Casalecchi e SandesFreitas (2014) para 2010. Eseb 2014 e $2018^{11 .}$

Embora esses dados não nos permitam afirmar qual é a direção causal (se o eleitor adequou a escolha do candidato à sua ideologia ou vice-versa), é evidente que ocorreu, em 2018, uma inversão da tendência de declínio da correlação entre ideologia e voto. Assim como a preferência partidária, a escolha eleitoral, em 2018, é mais ideologicamente consistente do que no período anterior.

As evidências aqui apresentadas dão suporte ao argumento de que o eleitorado reagiu ao contexto de maior polarização ideológica, promovido, em grande medida, pela reorganização e mobilização da direita na política brasileira. Elas indicam que a abordagem contextualista pode contribuir, de forma substantiva, para entender a articulação entre a dinâmica macrossocial e a estruturação ideológica do eleitor brasileiro.

Mas será que essa consistência entre ideologia e voto, em 2018, se mantém em modelos multivariados e com medidas mais sofisticadas de ideologia? Na próxima seção, testaremos se posições ideológicas influenciaram o voto para presidente em 2018.

${ }^{11}$ A classificação das candidaturas encontra-se na Tabela A3 dos Anexos. 


\section{Ideologia e voto em 2018}

Na seção anterior, argumentamos que o grau de consistência ideológica do eleitor não depende apenas de seus atributos individuais, mas é influenciado também pelo contexto, em função do grau de estruturação ideológica da política e do debate público. Identificamos, então, uma mudança de contexto, no Brasil, com a reorganização da direita e, consequentemente, a (re)ideologização da política brasileira. Em seguida, apresentamos evidências do declínio (2003-2014), seguido por um aumento, em 2018, da identificação ideológica do eleitor e da correlação entre ideologia, voto e partidarismo. Argumentamos, então, que essa congruência entre as mudanças de contexto e o grau de consistência entre ideologia e comportamento político sugere que o contexto importa.

Nesta seção, testamos se o voto para presidente em 2018 foi ideologicamente orientado. Com esse objetivo, decompomos a ideologia em suas duas expressões (simbólica e operacional) e utilizamos três variáveis para mensurar distintas dimensões ideológicas.

\section{Medidas de ideologia}

Para realizar uma análise mais cuidadosa da influência da ideologia sobre o voto, utilizaremos diversos indicadores capazes de captar as duas expressões da ideologia, a simbólica e a operacional (Ellis e Stimson, 2012). A ideologia simbólica diz respeito aos significantes esquerda-direita (ou liberal-conservador), situados numa escala, tal como apresentada na primeira seção deste artigo. A ideologia operacional, por sua vez, refere-se às posições dos eleitores em relação a uma série de assuntos públicos, tais como a distribuição de renda, o aborto, o meio ambiente e os direitos de minorias.

A ideologia simbólica tem apenas uma dimensão (a localização numa escala esquerda-direita ou liberal-conservador). Já a ideologia operacional é multidimensional e, portanto, a construção de seus indicadores requer que as variáveis captem as posições dos indivíduos em relação às diversas dimensões do debate ideológico.

Temos aqui de considerar que as noções de esquerda e direita se transformaram radicalmente na segunda metade do século $\mathrm{XX}$, incorporando pautas distintas das tradicionais clivagens de classe, tais como as questões de gênero e ambientais, e o autoritarismo (Silva, 2017). Além disso, pesquisas feitas em várias partes do mundo apontam que as crenças da maioria dos indivíduos não se estruturam de forma unidimensional e suas preferências e posições em relação ao conjunto de questões "ideológicas" constituem dimensões fatoriais independentes e não necessariamente articuladas entre si (Layman e Carsey, 2002). Desse modo, a maioria do eleitorado combina posições conservadoras numa dimensão com posições liberais em outra, enquanto apenas uma minoria é consistente nas duas dimensões. 
Carmines, Ensley e Wagner (2012b) mostram que as crenças do eleitorado americano se dividem em duas dimensões, uma econômica, em que se inserem os temas clássicos do papel do Estado e da desigualdade econômica, e uma social, que inclui temas "novos", como as questões raciais e de gênero. Segundo os autores, as posições do eleitor quanto a esses assuntos têm relação com seu voto e sua identificação partidária (Carmines, Ensley e Wagner, 2012a). Aplicando o modelo multidimensional ao caso brasileiro, Silva (2017) mostrou que a ideologia (operacional) dos brasileiros se organiza em três dimensões diferentes: econômica, social e relativa à ordem.

No presente artigo, tentamos lidar com essa complexidade. Além da dimensão econômica, relativa à pobreza e à desigualdade, e da dos costumes, relativa a valores morais e direitos das minorias, incluímos uma terceira dimensão, que se refere à segurança pública. Entendemos que tal divisão faz sentido para a política brasileira, considerando a crescente e intensa defesa da direita em relação à adoção de políticas firmes contra criminalidade (Faganello, 2015; Almeida, 2007; Quadros e Madeira, 2018). O mesmo pode ser observado em outros países da América Latina, nos quais eleitores e partidos de direita estão mais propensos que os de esquerda a apoiar medidas duras de combate ao crime (Visconti, 2020)12. Usando como fonte o Lapop 2019, encontramos um conjunto de quatro indicadores da ideologia. Um deles no nível simbólico, construído a partir da localização na escala, tal qual usamos na seção anterior ${ }^{13}$. E os outros três indicadores, criados a partir de três perguntas sobre o posicionamento dos entrevistados a respeito de assuntos públicos ${ }^{14}$. Para medir a dimensão dos costumes, usamos uma pergunta sobre a concordância do entrevistado quanto aos homossexuais terem o direito de se casar. A dimensão econômica foi construída a partir de uma pergunta sobre o apoio à adoção, por parte do Estado, de políticas firmes no combate à desigualdade de renda entre ricos e pobres. Para medir a dimensão de segurança pública, utilizamos uma pergunta sobre o apoio à pena de morte para quem comete assassinato.

$\mathrm{Na}$ construção desses três indicadores das dimensões da ideologia operacional, as perguntas foram mantidas em seu formato original, alterando-se somente o sentido das escalas de Likert, de tal forma que posições mais próximas da direita, ou seja, posições mais conservadoras nos costumes e menos afeitas a políticas de combate às desigualdades de renda, assumissem os maiores valores e as posições mais próximas da esquerda, os menores. A pergunta sobre segurança (binária) foi codificada de acordo com a mesma lógica,

\footnotetext{
12 Em Singer (2000), o tema da "ordem" tem outro significado. O autor analisa as atitudes dos eleitores em relação à intervenção em sindicatos e controle dos protestos, greves e manifestações populares e conclui que o apoio à preservação da ordem social é um dos principais traços ideológicos que distinguem a direita da esquerda no Brasil. Como essas variáveis não constam no Lapop 2019, não foi possível incluí-las nos nossos modelos.

13 Aqueles eleitores que se localizaram entre os valores 1 e 3 foram agrupados como localizados à esquerda; aqueles que optaram por valores entre 4 e 7 , ao centro; e à direita, aqueles que se localizaram entre os pontos 8 e 10.

${ }^{14}$ As perguntas utilizadas são apresentadas no Quadro 1 e 2, nos Anexos.
} 
com a discordância com a adoção de pena de morte para homicidas como categoria de referência.

\section{Resultados e discussão}

A influência da ideologia sobre o voto em Jair Bolsonaro foi estimada em cinco modelos de regressão logística binomial, sendo a variável dependente o voto no primeiro turno de 2018, com o voto em Bolsonaro codificado como 1 e o voto nos demais candidatos, 0 . Como controles, incluímos sexo, idade, escolaridade, ser beneficiário do programa Bolsa Família, renda, identificação partidária e religião. O primeiro modelo inclui a medida de ideologia simbólica do eleitor, construída com base na sua autolocalização. Os demais modelos testam as dimensões operacionais da ideologia, separadas e em conjunto.

Tabela 1

Ideologia e voto no Bolsonaro

\begin{tabular}{|c|c|c|c|c|c|}
\hline \multirow[t]{2}{*}{ Variáveis } & \multicolumn{5}{|c|}{ Coeficientes exponenciados } \\
\hline & Modelo 1 & Modelo 2 & Modelo 3 & Modelo 4 & Modelo 5 \\
\hline \multirow{2}{*}{ Centro } & $0.375^{* * *}$ & $0.375^{* * *}$ & & & \\
\hline & $(0.212)$ & $(0.212)$ & & & \\
\hline \multirow[t]{2}{*}{ Esquerda } & $0.241^{* * *}$ & & & & \\
\hline & $(0.262)$ & & & & \\
\hline \multirow[t]{2}{*}{ Dim. costumes } & & $1.064 * *$ & & & $1.072 * *$ \\
\hline & & $(0.027)$ & & & $(0.028)$ \\
\hline \multirow[t]{2}{*}{ Dim. econômica } & & & 0.991 & & 0.957 \\
\hline & & & $(0.046)$ & & $(0.048)$ \\
\hline \multirow[t]{2}{*}{ Dim. segurança } & & & & $1.659 * * *$ & $1.648 * * *$ \\
\hline & & & & $(0.135)$ & $(0.137)$ \\
\hline \multirow[t]{2}{*}{ IP outros partidos } & 1.503 & 1.663 & 1.573 & 1.633 & $1.760 *$ \\
\hline & $(0.321)$ & $(0.329)$ & $(0.315)$ & $(0.313)$ & $(0.325)$ \\
\hline \multirow[t]{2}{*}{ IP PSL } & $21,209,198.000 * * *$ & $28.645 * * *$ & $28.119 * * *$ & $26.007 * * *$ & $26.547 * * *$ \\
\hline & $(0.271)$ & $(1.044)$ & $(1.040)$ & $(1.052)$ & $(1.061)$ \\
\hline \multirow[t]{2}{*}{ IP PT } & $0.098 * * *$ & $0.078 * * *$ & $0.086 * * *$ & $0.082 * * *$ & $0.071 * * *$ \\
\hline & $(0.370)$ & $(0.396)$ & $(0.373)$ & $(0.379)$ & $(0.391)$ \\
\hline \multirow[t]{2}{*}{$\begin{array}{l}\text { Recebe Bolsa } \\
\text { Família }\end{array}$} & $0.333 * * *$ & $0.386 * * *$ & $0.384 * * *$ & $0.406 * * *$ & $0.409 * * *$ \\
\hline & $(0.267)$ & $(0.237)$ & $(0.239)$ & $(0.236)$ & $(0.233)$ \\
\hline \multirow[t]{2}{*}{ Idade } & 1.008 & $1.013 * *$ & $1.017 * * *$ & $1.019 * * *$ & $1.015^{* *}$ \\
\hline & $(0.007)$ & $(0.006)$ & $(0.006)$ & $(0.006)$ & $(0.006)$ \\
\hline \multirow[t]{2}{*}{ Homem } & $1.603 * * *$ & $1.902 * * *$ & $1.962 * * *$ & $1.931 * * *$ & $1.841^{* * *}$ \\
\hline & $(0.178)$ & $(0.168)$ & $(0.169)$ & $(0.176)$ & $(0.176)$ \\
\hline Anos de estudo & 0.966 & 1.004 & 0.990 & 1.002 & 1.011 \\
\hline
\end{tabular}




\begin{tabular}{|c|c|c|c|c|c|}
\hline \multirow[t]{2}{*}{ Variáveis } & \multicolumn{5}{|c|}{ Coeficientes exponenciados } \\
\hline & $(0.027)$ & $(0.027)$ & $(0.026)$ & $(0.026)$ & $(0.027)$ \\
\hline \multirow[t]{2}{*}{ Renda 2} & 1.398 & 1.184 & 1.172 & 1.230 & 1.275 \\
\hline & $(0.279)$ & $(0.235)$ & $(0.236)$ & $(0.238)$ & $(0.244)$ \\
\hline \multirow[t]{2}{*}{ Renda 3} & 1.004 & 1.045 & 1.044 & 1.057 & 1.083 \\
\hline & $(0.257)$ & $(0.226)$ & $(0.221)$ & $(0.224)$ & $(0.232)$ \\
\hline \multirow[t]{2}{*}{ Renda 4} & 1.128 & 1.154 & 1.149 & 1.242 & 1.323 \\
\hline & $(0.304)$ & $(0.297)$ & $(0.283)$ & $(0.292)$ & $(0.302)$ \\
\hline \multirow[t]{2}{*}{ Católico } & $0.453 * * *$ & $0.472 * * *$ & $0.410 * * *$ & $0.371 * * *$ & $0.442 * * *$ \\
\hline & $(0.194)$ & $(0.202)$ & $(0.187)$ & $(0.197)$ & $(0.219)$ \\
\hline \multirow[t]{2}{*}{ Outros } & $0.304 * * *$ & $0.364 * * *$ & $0.284 * * *$ & $0.277 * * *$ & $0.352 * * *$ \\
\hline & $(0.272)$ & $(0.270)$ & $(0.256)$ & $(0.265)$ & $(0.284)$ \\
\hline \multirow[t]{2}{*}{ Constant } & $1.474 * * *$ & -0.383 & 0.079 & $-0.881^{*}$ & -1.216 \\
\hline & $(0.514)$ & $(0.494)$ & $(0.476)$ & $(0.474)$ & $(0.284)$ \\
\hline Akaike Inf. Crit. & 640.854 & 711.106 & 725.014 & 692.270 & 684.014 \\
\hline $\mathrm{N}$ & 846 & 886 & 896 & 868 & 861 \\
\hline
\end{tabular}

Fonte: Lapop 2019.

Significância: *p $<0.1 ; * * p<0.05 ; * * * p<0.01$.

Erros-padrão entre parênteses.

De forma geral, observa-se que, assim como em eleições anteriores, vários fatores investigados pela literatura recente sobre o voto no Brasil contribuem para explicar a escolha do eleitor no último pleito. Esse é o caso do Programa Bolsa Família. Ser atendido por esse programa diminui as chances de voto em Bolsonaro. O PT manteve-se como a referência partidária dos beneficiários do programa (Nicolau, 2014; Zucco Júnior, 2013; Lício, Rennó e Castro, 2009). Isso releva a existência de vínculos mais duradouros do que o esperado pelas lógicas do clientelismo ou do voto econômico entre os beneficiários desse programa e o PT.

A identificação partidária também apresentou efeitos significativos nos modelos e no sentido esperado, confirmando a importância do partidarismo na estruturação do comportamento político do brasileiro (Carreirão e Kinzo, 2004; Carreirão, 2007). Quanto aos demais controles, confirmando as principais pesquisas eleitorais divulgadas pela imprensa durante a campanha, homens e evangélicos tiveram mais chances de voto em Jair Bolsonaro. Passamos agora para a análise das nossas variáveis de interesse, a ideologia simbólica e as dimensões operacionais da ideologia.

Confirmando nossas expectativas, a identificação ideológica apresentou efeito significativo sobre o voto. Situar-se na esquerda e no centro da escala ideológica diminui as chances do voto em Jair Bolsonaro. Os eleitores no centro e na esquerda da escala tiveram, 
respectivamente, $62,5 \%$ e $75,9 \%$ menos chances de votar em Bolsonaro do que os que estão na direita ${ }^{15}$.

Nas demais colunas, apresentamos os modelos com as posições dos eleitores em relação a um conjunto de assuntos que opõem esquerda e direita. Esses modelos têm a vantagem de atenuar o problema de endogeneidade, já que, no caso da ideologia simbólica, o eleitor pode ajustar, com mais facilidade, a sua posição para corresponder à escolha eleitoral. Outra vantagem é que a posição em relação a assuntos públicos é uma medida que tem maior grau de precisão do que a autolocalização. Assim, além de validarem o resultado do modelo anterior, esses quatro últimos modelos permitem testar se o voto ideológico em Jair Bolsonaro é robusto, incluindo também a sua expressão operacional (Ellis e Stimson, 2012). Por último, como cada uma das dimensões tem autonomia em relação às outras, esses modelos permitem uma análise mais nuançada do efeito da ideologia sobre o voto.

Como mostra o modelo 2, a variável que mede a dimensão dos costumes apresenta efeito estatisticamente significativo sobre o voto. A cada ponto que o eleitor se desloca na direção de discordar que casais homossexuais tenham o direito de se casar, aumenta, em média, 6,4\% a sua chance de votar em Bolsonaro em comparação com os demais candidatos. A mesma relação positiva entre conservadorismo e voto em Bolsonaro pode ser observada no modelo 4. Quem se diz favorável à adoção de pena de morte para quem comete assassinato teve, em média, 65,9\% mais chances de votar em Bolsonaro do que quem se diz contrário à medida.

Tal resultado vai ao encontro do nosso argumento de que, em contextos em que as elites políticas se posicionam ideologicamente com clareza, suas sinalizações contribuem para que os eleitores percebam e orientem o seu voto pelas questões em disputa. Os eleitores brasileiros mais conservadores parecem ter reagido às mensagens que identificam a direita com a preservação dos papéis de gênero tradicionais e penas mais duras para criminosos, votando de forma consistente com as suas posições ideológicas.

Já a dimensão econômica da ideologia (modelo 3) não apresentou significância estatística. Os eleitores de Jair Bolsonaro não se diferenciam dos demais em relação à adoção de políticas firmes, por parte do Estado, de combate à desigualdade de renda entre ricos e pobres. Tal fato reitera achados recorrentes em estudos anteriores quanto à ausência de diferença entre os brasileiros em relação a essa dimensão da ideologia, a maioria deles manifestando atitudes estatistas e favoráveis à redução da pobreza (Singer, 2000; Bonifácio, Casalecchi e Sandes-Freitas, 2014; Borges e Vidigal, 2018).

A ideologia da direita que emergiu e se reorganizou nos últimos anos não tem uma direção unívoca no caso das questões econômicas, sendo muito mais salientes suas posições em relação à segurança pública e aos costumes (Quadros e Madeira, 2018). Além disso, as mensagens de campanha de Bolsonaro e suas posições prévias de cunho estatista - que

15 Para se chegar a esse valor, assim como aos demais, foi feito o seguinte cálculo: (exp(coef) -1) * 100. Como indicado na Tabela 1, optamos por reportar esses coeficientes já exponenciados. 
contrastavam com o discurso pró-mercado do seu então futuro ministro da Economia geraram "pistas" ambíguas para os seus eleitores a respeito da posição da direita e do bolsonarismo sobre o tema.

Em resumo, diversos indicadores de ideologia apontam para a mesma direção: eleitores com posições mais à direita apresentaram maior probabilidade de votar no candidato com quem compartilham valores. Tais resultados reforçam os achados descritivos e longitudinais discutidos na primeira seção deste artigo e mostram o potencial analítico da perspectiva, ainda pouco utilizada no Brasil, que considera os efeitos do contexto sobre a maior ou menor consistência ideológica dos eleitores (Nie e Andersen, 1974; Stimson, 1975; Nie e Rabjohn, 1979; Bafumi e Shapiro, 2009; Abramowitz, 2010; Hetherington, 2001; Fiorina, Abrams e Pope, 2006; Fiorina e Abrams, 2008; Carreirão, 2007, 2008).

O brasileiro, a partir de 2014, tem se posicionado mais na escala esquerda-direita e, em 2018, mostra maior coerência entre, de um lado, a sua localização nessa escala e, de outro, a sua identificação partidária e o voto. Além disso, suas opiniões e posições em relação a alguns dos assuntos que dividem esquerda e direita no Brasil, hoje, revelaram ser bons preditores do voto.

Esse maior alinhamento ideológico dos eleitores representa uma inversão da tendência de declínio do voto ideológico, constatada por Carreirão $(2007,2008)$ e Bonifácio, Casalecchi e Sandes-Freitas (2014), quando o sistema partidário perdia seus contornos ideológicos (Zucco Júnior, 2011).

O conjunto de dados que apresentamos neste artigo reforça o argumento de que 0 contexto importa. A superação, no parlamento, nas ruas e nas mídias da "síndrome da direita envergonhada" (Quadros e Madeira, 2018; Melo, Câmara e Santos, 2020; Saad-Filho e Boito, 2016; Alonso, 2017; Avritzer, 2017; Chaloub e Perlatto, 2016) e, principalmente, a oferta de uma candidatura de extrema direita, em 2018, organizaram ideologicamente o debate público e, dessa forma, contribuíram para aproximar o voto das posições políticas dos eleitores.

\section{Considerações finais}

O eleitorado brasileiro tem manifestado um aumento de consistência ideológica, inclusive na decisão do voto em 2018. Confirmando uma recente alteração de padrão entre ideologia e comportamento político, é nítida a presença do voto ideológico em 2018. Eleitores que, na escala ideológica, se identificam com a direita e que estão mais preocupados com a "ordem", nos costumes e na segurança, votaram de acordo com esses valores.

A exceção são as atitudes em relação à dimensão econômica da ideologia. Isso não significa que estejamos diante de uma "guerra cultural", com o deslocamento do conflito do campo da economia para o dos valores (Fiorina, Abrams e Pope, 2006). Aliás, não há nada de novo nas atitudes dos brasileiros em relação à dimensão econômica. Desde 1989, estudos mostram, recorrentemente, um forte apoio entre os brasileiros, independentemente de 
posição ideológica, à igualdade econômica e a um Estado proativo (Singer, 2000; Samuels e Zucco Júnior, 2018).

O significado dessa ausência de clivagem ainda precisa ser investigado. Uma possível linha de interpretação dessa constante na opinião pública brasileira pós-1989 é a que propomos para o contexto atual. Na formação recente da identidade e da mobilização da direita entre elites e ativistas políticos, o componente econômico não tem a mesma saliência e homogeneidade que as demais dimensões. Isso pode ser observado durante a campanha eleitoral de 2018, quando houve ampla disseminação e saliência das posições ideológicas no debate provocado por Bolsonaro. Como a direção do voto ideológico depende, em parte, das dimensões realçadas pelo fluxo informacional (Zaller, 1992), é possível que, se a dimensão econômica tivesse adquirido maior saliência em 2018, outras clivagens tivessem sido também ativadas (Schattschneider, 1960).

Do ponto de vista metodológico, essa diferença de efeito entre as dimensões da ideologia evidencia a relevância da utilização de indicadores multidimensionais e reforça a tese de que diferentes contextos políticos podem estimular diferentes tipos de alinhamentos ideológicos, realçando mais ora uma dimensão, ora outra.

As evidências e análises aqui apresentadas não nos autorizam a concluir que os brasileiros se tornaram peritos em ideologia, nem que as mudanças recentemente experimentadas sejam duradouras. Essa é uma outra vantagem da abordagem contextualista: evita conclusões precipitadas, seja a de que o eleitor mediano está fadado a não entender nada sobre esquerda e direita, seja a de que ele dá conta do recado com o pouco que sabe.

Importante observar que, em termos teóricos e normativos, nosso modelo não supõe que os cidadãos mais informados tenham um perfil ideológico preestabelecido. Portanto, os resultados que apresentamos independem de suas consequências políticas. Também não supomos que a polarização seja condição suficiente (ou mesmo necessária) para que haja incremento do comportamento ideologicamente consistente. A abordagem que adotamos supõe apenas que contextos que colocam em evidência as diferenças entre as alternativas políticas estimulam uma resposta mais ideológica do eleitor.

O nosso argumento passa longe da ideia de que a ideologia foi o fator decisivo na escolha eleitoral de 2018. Outros fatores, como antipetismo e antipartidarismo generalizado (Fuks, Ribeiro e Borba, 2020), asseguraram um apoio eleitoral bem mais amplo e consistente. Mas é difícil explicar a decisão do eleitor em 2018 sem considerar a sua reação às posições e propostas eleitorais da direita.

Estudos de natureza experimental ou longitudinal, com mais dados e pontos no tempo, seriam necessários para confirmar se, no Brasil, a relação entre contexto político e consistência ideológica segue o padrão já identificado pela literatura internacional. Esperamos que futuras pesquisas possam avançar também na explicação de outras consequências da polarização sobre o comportamento político do brasileiro. 


\section{Referências bibliográficas}

ABRAmowitz, A. I. The disappearing center: engaged citizens, polarization, and American democracy. New Haven, London: Yale University Press, 2010.

AlmeidA, A. C. A cabeça do brasileiro. São Paulo: Record, 2007.

Alonso, A. "A política das ruas: protestos em São Paulo de Dilma a Temer". Novos Estudos Cebrap, São Paulo, vol. 37, no 1, p. 49-58, jun. 2017.

AVRITZER, L. "Participation in democratic Brazil: from popular hegemony and innovation to middle-class protest". Opinião Pública, Campinas, vol. 23, no 1, p. 43-59, abr. 2017.

BAfUmi, J.; ShaPIRO, R. Y. "New partisan voter". The Journal of Politics, vol. 71, no 1, p. 1-24, 2009.

BONIFÁCIO, R.; CASALECCHI, G.; SANDES-FREITAS, V. Ideologia e voto nas eleições presidenciais brasileiras. In: BONIFÁCIO, R.; CASALECCHI, G.; DEUS, C. (orgs.). O voto para presidente no Brasil: condicionantes e fatores explicativos (1989-2010). Curitiba: Editora Íthala, p. 285-316, 2014.

Borges, A.; VidigAL, R. "Do lulismo ao antipetismo? Polarização, partidarismo e voto nas eleições presidenciais brasileiras". Opinião Pública, Campinas, vol. 24, no 1, p. 53-89, jan.-abr. 2018.

Bustikova, L.; Zechmeister, E. J. Voting in new(er) democracies. In: ARZheimer, K.; Evans, J.; LeWisBECK, M. S. (orgs.). The Sage handbook of electoral behaviour. Londres: Sage Publications, p. 92-134, 2017.

Campbell, A., et al. The American voter. New York: John Wiley, 1960.

CARmines, G. E.; Ensley, M. J.; WAgner, M. W. "Who fits the left-right divide? Partisan polarization in the American". American Behavioral Scientist, Madison, vol. 56, no 12, p. 1.631-1.653, out. 2012 a.

18, out. 2012b.

"Political ideology in American politics: one, two or none?". The Forum, vol. 10, no 3, p. 1-

CARREIRÃo, Y. S. "A decisão do voto nas eleições presidenciais do Brasil (1989 a 1998): a importância do voto por avaliação de desempenho". Tese de Doutorado em Ciência Política. USP, São Paulo, 2000.

p. 54-79, 2002.

"Identificação ideológica e voto para presidente". Opinião Pública, Campinas, vol. 8, no 1,

"Identificação ideológica, partidos e voto na eleição presidencial de 2006". Opinião Pública, Campinas, vol. 13, no 2, p. 307-339, nov. 2007.

"Opiniões políticas e sentimentos partidários dos eleitores brasileiros". Opinião Pública, Campinas, vol. 14, no 2, nov. 2008.

CARreirÃo, Y. S.; Kinzo, M. D., "Partidos políticos, preferência partidária e decisão eleitoral no Brasil (1989-2002)". Dados, Rio de Janeiro, vol. 47, no 1, p. 131-168, 2004.

CASTRO, M. M. M. "O comportamento eleitoral no Brasil: diagnóstico e interpretações". Teoria e Sociedade, Belo Horizonte, vol. 1, no 1, p. 126-168, 1997.

Chaloub, J. G. S.; Perlatto, F. "Intelectuais da 'nova direita' brasileira: ideias, retórica e prática política". Insight Inteligência, Rio de Janeiro, vol. 1, no 72, p. 25-42, 2016.

Cintra. A. O. "Partidos políticos em Belo Horizonte: um estudo do eleitorado". Dados, no 5, p. 82-112, 1968. 
MARIO FUKS; PEDRO HENRIQUE MARQUES

CONVERSE, P. "The nature of belief systems in mass publics". Critical Review, London, vol. 18, no 1-3, p. 1-74, [1964] 2006a.

329, 2006 b.

"Democratic theory and electoral reality". Critical Review, London, vol. 18, no 1-3, p. 297-

DALTON, R. J. Left-right orientations, context, and voting choices. In: DALTON, R. J.; ANDERSON, C. J. (eds.). Citizens, context, and choice: how context shapes citizens' electoral choices. New York: Oxford University Press, p. 103-125, 2011.

DATAfolha/Brasil-1989/SET- 00186. Intenção de Voto Presidente Vi - Cultura Política i- Cedec. In: Banco de Dados do Cesop/Unicamp. Disponível em:

<https://www.cesop.unicamp.br/por/banco_de_dados/v/421>. Acesso em: 15 fev. 2020.

DatAfolha/Brasil-1993/FeV- 00318. Pena de Morte/Plebiscito. In: Banco de Dados do Cesop/Unicamp. Disponível em: <https://www.cesop.unicamp.br/por/banco_de_dados/v/1380>. Acesso em: 15 fev. 2020.

Datafolha/Brasil-1999/Jun- 01045. Avaliação Presidente Fernando HenRique Cardoso /Intenção de Votar para Presidente/Avaliação Plano Real/Avaliação Congresso Nacional. In: Banco de Dados do Cesop/Unicamp. Disponível em: <https://www.cesop.unicamp.br/por/banco_de_dados/v/174>. Acesso em: 15 fev. 2020.

DATAFOLHA 2000 e 2003. Disponível em:

<https://www.cesop.unicamp.br/por/banco_de_dados/v/174>. Acesso em: 21 fev. 2020.

Ellis, C.; Stimson, J. A. Ideology in America. New York: Cambridge University Press, 2012.

Eseb-2002-Estudo Eleitoral Brasileiro - Cesop-FGV/Brasil-2002/nov-01838. In: Banco de Dados do Cesop/Unicamp. Disponível em: <https://www.cesop.unicamp.br/por/eseb/ondas/5>. Acesso em: 21 out. 2019.

ESEB-2014-Estudo Eleitoral Brasileiro - Cesop-Ibope/Brasil-2014/nov-03928. In: Banco de Dados do Cesop/Unicamp. Disponível em: <https://www.cesop.unicamp.br/por/eseb/ondas/8>. Acesso em: 21 out. 2019.

Eseb-2018-Estudo Eleitoral Brasileiro - Cesop-Ibope/Brasil-2018/nov- 04622. In: Banco de Dados do Cesop/Unicamp. Disponível em: <https://www.cesop.unicamp.br/por/eseb/ondas/11>. Acesso em: 21 out. 2019.

FAgAnello, M. A. Bancada da bala: uma onda na maré conservadora. In: Cruz, S. V.; KAYSEL, A.; CoDAS, G. (orgs.). Direita, volver!: o retorno da direita e o ciclo político brasileiro. São Paulo: Editora Fundação Perseu Abramo, p. 145-162, 2015.

Fernandes, D. C.; Vieira, A. M. "A direita mora do mesmo lado da cidade: especialistas, polemistas e jornalistas". Novos Estudos Cebrap, São Paulo, vol. 38, nº 1, p. 157-182, jan.-abr. 2019.

Fiorina, M. P.; Abrams, S. J. "Political polarization in the American public". Annual Review of Political Science, Palo Alto, vol. 11, no 1, p. 563-588, jun. 2008.

Fiorina, M. P.; Abrams, S. J.; Pope, J. C. Culture war? The myth of a polarized America. New York: Pearson Education, 2006.

FUKS, M.; RIBEIRO, E.; BORBA, J. "From antipetismo to generalized antipartisanship: the impact of rejection of political parties on the 2018 vote for Bolsonaro. Brazilian Political Science Review, vol. 15, no 1 , nov. 2020. 
Hetherington, M. J. "Resurgent mass partisanship: the role of elite polarization article". American Political Science Review, Cambridge, vol. 95, no 3, p. 619-631, set. 2001.

Kinder, D. "Belief systems today". Critical Review, Cambridge, vol. 18, no 1-3, p. 197-216, jan. 2006.

KInDER, D.; KALMOE, N. Neither liberal nor conservative: ideological innocence in the American public. Chicago: University of Chicago Press, 2017.

LACHAT, R. "The impact of party polarization on ideological voting". Electoral Studies, Londres, vol. 27, no 4, p. 687-698, 2008.

LAMOUNIER, B. O voto em SP: 1970-1978. In: LAMOUNIER, B. (org.). Voto de desconfiança: eleições e mudança política no Brasil: 1970-1979. Petrópolis: Vozes, p. 15-80, 1980.

LAPOP-2007/BRASIL-2007/MAR-ABR 2007. In: Banco de Dados do Lapop/Wanderbilt. Disponível em: <https://www.vanderbilt.edu/lapop/>. Acesso em: 21 out. 2019.

LAPOP-2008/BRASIL-2008/MAR-ABR 2008. In: Banco de Dados do Lapop/Wanderbilt. Disponível em: <https://www.vanderbilt.edu/lapop/>. Acesso em: 21 out. 2019.

LAPOP-2010/BRASIL-2010/MAR-ABR 2010. In: Banco de Dados do Lapop/Wanderbilt. Disponível em: <https://www.vanderbilt.edu/lapop/>. Acesso em: 21 out. 2019.

LAPOP-2012/BRASIL-2012/MAR-ABR 2012. In: Banco de Dados do Lapop/Wanderbilt. Disponível em: <https://www.vanderbilt.edu/lapop/>. Acesso em: 21 out. 2019.

LAPOP-2014/BRASIL-2014/MAR-ABR 2014. In: Banco de Dados do Lapop/Wanderbilt. Disponível em: <https://www.vanderbilt.edu/lapop/>. Acesso em: 21 out. 2019.

LAPOP-2017/BRASIL-2017/ABR-MAI 2017. In: Banco de Dados do Lapop/Wanderbilt. Disponível em: <https://www.vanderbilt.edu/lapop/>. Acesso em: 21 out. 2019.

LAPOP-2019/BRASIL-2019/JAN-MAR 2019. In: Banco de Dados do Lapop/Wanderbilt. Disponível em: <https://www.vanderbilt.edu/lapop/>. Acesso em: 21 out. 2019.

LAYMAN, G. C.; CARSEY, T. M. "Party polarization and party structuring of policy attitudes: a comparison of three NES panel studies". Political Behavior, Berlin, vol. 24, p. 199-236, set. 2002.

LeVEndusky, M. S. "Clearer cues, more consistent voters: a benefit of elite polarization". Political Behavior, Berlin, vol. 32, no 1, p. 111-131, mar. 2010.

Licio, E. C.; Rennó, L.; CAStRo, H. C. O. "Bolsa Família e voto na eleição presidencial de 2006: em busca do elo perdido". Opinião Pública, Campinas, vol. 15, no 1, p. 31-54, 2009.

MASON, L. Uncivil agreement: how politics became our identity. Chicago: University of Chicago Press, 2018.

Melo, C. R.; CÂMARA, R.; SAntos, M. What can ideology tell us? An analysis of deputies and parties in the Brazilian, Chilean and Uruguayan legislatives. In: AlCÁNTARA SÁEZ, M.; GARCíA MonTERO, M.; RIVAS PÉrez, C. (eds.). Politics and political elites in Latin America. Boulder: Springer International Publishing, 2020.

MessenberG, D. "A direita que saiu do armário: a cosmovisão dos formadores de opinião dos manifestantes de direita brasileiros". Revista Sociedade e Estado, Brasília, vol. 32, no 3, p. 621-648, set.-dez. 2017.

Nicolau, J. "Determinantes do voto no primeiro turno das eleições presidenciais brasileiras de 2010: 
MARIO FUKS; PEDRO HENRIQUE MARQUES

uma análise exploratória". Opinião Pública, Campinas, vol. 20, n 3, p. 311-325, dez. 2014.

NiE, N. H.; ANDERSEN, K. "Mass belief systems revisited: political change and attitude structure". The Journal of Politics, Atlanta, vol. 36, no 3, p. 540-591, ago. 1974.

NiE, N. H.; RABJOHN, J. A. "Revisiting mass belief systems revisited: or, doing research is like watching a tennis match". American Journal of Political Science, Bloomington, vol. 23, no 1, p. 139-175, fev. 1979.

Oliveira, C.; Turgeon, M. "Ideologia e comportamento político no eleitorado brasileiro". Opinião Pública, Campinas, vol. 21, no 3, p. 574-600, dez. 2015.

PenteAdo, C., LeRner, C. "A direita na rede: mobilização online no impeachment de Dilma Rousseff". Em Debate, Belo Horizonte, vol. 10, no 1, p. 12-24, abr. 2018.

Pierucci, A. F. O. "As bases da nova direita". Novos Estudos Cebrap, São Paulo, no 19, p. 26-45, dez. 1987. Ciladas da diferença. São Paulo: Editora 34, 1999.

POWER, T.; ZUCCO Júnior, C. "Estimating ideology of Brazilian legislative parties, 1990-2005: a research communication". Latin American Research Review, Pittsburgh, vol. 44, no 1, p. 218-246, 2009.

Quadros, M. P. R; MAdeirA, R. M. "Fim da direita envergonhada? Atuação da bancada evangélica e da bancada da bala e os caminhos da representação do conservadorismo no Brasil". Opinião Pública, Campinas, vol. 24, no 3, set.-dez. 2018.

REIS, F. W. Classe social e opção partidária: as eleições de 1976 em Juiz de Fora. In: REIS, F. W. (org.). Os partidos e o regime: a lógica do processo eleitoral brasileiro. São Paulo: Símbolo, p. 218287, 1978.

"Identidade, política e a teoria da escolha racional". Revista Brasileira de Ciências Sociais, São Paulo, vol. 3, no 6, fev. 1988.

RochA, C. "'Menos Marx, mais Mises': uma gênese da nova direita brasileira (2006-2018)". Tese de Doutorado em Ciência Política. USP, São Paulo, 2018.

RodRIgUeS, L. M. Quem é quem na Constituinte: uma análise sociopolítica dos partidos e deputados. São Paulo: OESP-Maltese, 1987.

SAAd-Filho, A.; Boito, A. "Brazil: the failure of the PT and the rise of the 'new right". Socialist Register, Londres, vol. 52, p. 213-230, 2016.

SAmuels, D. "A evolução do petismo (2002-2008)". Opinião Pública, Campinas, vol. 14, no 2, p. 302318, nov. 2008.

SAMUELS, D. J.; Zucco JúNioR, C. Partisans, antipartisans, and nonpartisans: voting behavior in Brazil. New York: Cambridge University Press, 2018.

SCHATTSCHNEIDER, E. E. The semi-sovereign people: a realist's view of democracy in America. New York: Holt, Rinehart and Winston, 1960.

SILVA, T. M. "Para além de esquerda e direita: a multidimensionalidade das crenças no Brasil contemporâneo (1989-2014)". Tese de Doutorado em Ciência Política. UnB, Brasília, 2017.

SINGER. A. Esquerda e direita no eleitorado brasileiro: a identificação ideológica nas disputas presidenciais de 1989 e 1994. São Paulo: Edusp, 2000. 
SINGER, M. "Elite polarization and the electoral impact of left-right placements: evidence from Latin America, 1995-2009". Latin American Research Review, Pittsburgh, vol. 51, no 2, p. 174-194, 2016.

Stimson, J. "Belief systems: constraint, complexity, and the 1972 election". American Journal of Political Science, Bloomington, vol. 19, no 3, p. 394-417, 1975.

TAROUCO, G. S.; MADEIRA, R. M. "Os partidos brasileiros segundo seus estudiosos: análise de um expert survey". Civitas - Revista Ciênciais Sociais, vol. 15, no 1, p. 24-39, 2015.

VEIGA, L. F. "Os partidos brasileiros na perspectiva dos eleitores: mudanças e continuidades na identificação partidária e na avaliação das principais legendas após 2002". Opinião Pública, Campinas, vol. 13 , no 2, p. 340-365, nov. 2007

VISCONTI, G. "Policy preferences after crime victimization: panel and survey evidence from Latin America". British Journal of Political Science, Cambridge University Press, vol. 50, no 4, p. 1.481-1495, out., 2020.

Wiesehomeier, N.; Benoit, K. Parties and presidents in Latin America: data from expert surveys in 18 Latin American countries, 2006-2007. [Data set]. University of Konstanz e Trinity College Dublin, 2007.

ZALLER, J. The nature and origins of mass opinion. New York: Cambridge University Press, 1992.

ZeChMeister, E.; CORRAL, M. "Individual and contextual constraints on ideological labels in Latin America". Comparative Political Studies, vol. 46, nº 6, p. 675-701, 2013.

ZUCCO JúNIOR, C. Esquerda, direita e governo. A ideologia dos partidos políticos brasileiros. In: POWER, T.; Zucco JúnIOR, C. (orgs.). O Congresso por ele mesmo: autopercepções da classe política brasileira. Belo Horizonte: Editora UFMG, 2011.

ZUCCO JúNIOR, C. "When payouts pay off: conditional cash transfers and voting behavior in Brazil 200210". American Journal of Political Science, Bloomington, vol. 57, no 4, p. 810-822, abr. 2013. 


\section{Anexos}

\section{Tabela A1}

Evolução da autolocalização ideológica, 1989-2019 (\% da população de eleitores)

\begin{tabular}{|c|c|c|c|c|}
\hline & \multicolumn{4}{|c|}{ Autolocalização ideológica } \\
\hline Ano & Esquerda & Centro & Direita & NS/NR \\
\hline 1989 & 12,7 & 40,8 & 22,4 & 24,2 \\
\hline 1993 & 17,7 & 33,8 & 34,8 & 13,8 \\
\hline 1999 & 17,3 & 37,2 & 23,8 & 21,5 \\
\hline 2000 & 17 & 35 & 20 & 21 \\
\hline 2003 & 16 & 39 & 28 & 16 \\
\hline 2007 & 15,2 & 45,9 & 20 & 18,9 \\
\hline 2008 & 11 & 47,5 & 17,8 & 23,6 \\
\hline 2010 & 11,16 & 45,8 & 18,57 & 24 \\
\hline 2012 & 20,7 & 43 & 20,3 & 15,9 \\
\hline 2014 & 19,3 & 42 & 22,3 & 16,3 \\
\hline 2017 & 29,1 & 41,2 & 21,9 & 7,9 \\
\hline 2019 & 21,7 & 39,4 & 31,5 & 7,4 \\
\hline
\end{tabular}

Fonte: Elaborada pelos autores com base no Datafolha 1989, 1993, 1999, 2000, 2003 e no Lapop 2007, 2008, 2010, 2012, 2014, 2017, 2019.

Tabela A2

Classificação dos partidos na escala ideológica ${ }^{16}$

\begin{tabular}{|l|c|}
\hline $\begin{array}{l}\text { Categoria } \\
\text { ideológica }\end{array}$ & Partidos \\
\hline Esquerda & PSOL (2.12); PCdoB (2,9); PT (3,96); PSB (4,64) \\
\hline Centro & PDT (5,39); PV; PPS (5,79); PMDB (6,76) \\
\hline Direita & PSDB (7,39); PTB (7,53); PSC (8,94); PP (9,59); DEM (9.97); PL; Novo; PSL \\
\hline
\end{tabular}

Fonte: Elaboração própria.

16 O valor numérico entre parênteses indica o score que o partido atingiu na nossa variável construída com base nos indicadores explicados na nota de rodapé número 11. Para os partidos para os quais não tínhamos dados em nenhuma das bases usadas para a construção do índice, baseamo-nos em Zucco Júnior (2011), uma vez que há uma grande proximidade entre essas classificações. Esse foi o caso do PV, categorizado como centro, e do PL, como direita. Para o Novo e o PSL, em relação aos quais não tínhamos dados nem na base usada para construção dos índices nem em Zucco Júnior (2011), valemo-nos do entendimento relativamente inconteste de que são partidos de direita. 


\begin{tabular}{|c|c|}
\hline Ano & Classificação das candidaturas na escala ideológica ${ }^{17}$ \\
\hline 2002 & 1=Lula e Zé Maria; 2=Ciro e Garotinho; 3=Serra \\
\hline 2006 & 1=Heloísa Helena; 2=Lula e Cristovam Buarque; 3=Alckmin \\
\hline 2010 & $\begin{array}{l}1=\text { Dilma Rousseff (PT), Rui Costa Pimenta } \\
(P C O), \text { Ivan Valente (PSOL) e José Maria (PSTU); } 2=\text { Marina Silva } \\
(P V) \text { e José Maria Eymael (PSDC); } 3=\text { José Serra (PSDB). }\end{array}$ \\
\hline 2014 & $\begin{array}{l}\text { 1=Luciana Genro, Mauro Iasi, Rui Costa Pimenta e Zé Maria; } 2=\text { Dilma; } 3=\text { Marina Silva e } \\
\text { Eduardo Jorge; 4=Aécio Neves e José Maria Eymael; 5=Pastor Everaldo e Levy Fidelix }\end{array}$ \\
\hline 2018 & $\begin{array}{c}\text { 1=Boulos e Haddad; 2= Marina Silva e Ciro Gomes; 3=Henrique Meirelles, Eymael e } \\
\text { Alckmin; 4=Daciolo, Bolsonaro, Amoêdo e Alvaro Dias }\end{array}$ \\
\hline
\end{tabular}

Fonte: Elaboração própria.

\section{Quadro 1}

\section{Pergunta utilizada na criação da variável que mede a dimensão simbólica da ideologia}

\begin{tabular}{|c|c|c|}
\hline Dimensão & Código e redação original & $\begin{array}{c}\text { Escala } \\
\text { original }\end{array}$ \\
\hline Simbólica & $\begin{array}{c}\text { L1. Hoje em dia, quando se conversa de tendências políticas, fala-se } \\
\text { de pessoas que simpatizam mais com a esquerda e de pessoas que } \\
\text { simpatizam mais com a direita. De acordo com o sentido político que } \\
\text { os termos "esquerda" e "direita" têm para o(a) sr./sra., onde o(a) } \\
\text { sr./sra. se situa nesta escala? }\end{array}$ & $\begin{array}{c}\text { (Esquerda) a } \\
10 \text { (Direita) }\end{array}$ \\
\hline
\end{tabular}

Fonte: Elaboração própria com base nas questões do Lapop 2019.

\footnotetext{
17 As classificações de 1989 a 2006 são de Carreirão (2000, 2007) e a de 2010 é de Bonifácio, Casalecchi e Sandes-Freitas (2014). Categorizações alternativas foram testadas em Carreirão (2007) para os anos de 2002 e 2006 sem, no entanto, provocar mudanças maiores que 0,04 no coeficiente de correlação. Apesar disso, decidimos que, para efeito de comparação, seria mais exigente usar as classificações testadas por ele que tiveram os maiores coeficientes de correlação. Também testamos categorizações alternativas para os anos 2014 e 2018. Em 2014, por exemplo, testamos o gamma com as candidaturas classificadas em três categorias, agrupando Dilma no grupo 1 (esquerda) - composto por Luciana Genro, Mauro Iasi, Rui Costa Pimenta e Zé Maria; Marina Silva e Eduardo Jorge no grupo 2 (centro); e os demais no grupo 3 (direita). Para efeito de comparação, a diferença do coeficiente de correlação gamma nesse caso também foi mínima, a classificação da Tabela 1 rendeu um gamma de 0,08 enquanto essa alternativa rendeu um de 0,078. Em 2018, também testamos outra categorização. No caso, a alternativa foi testar com 1=Boulos; 2=Haddad e Ciro; $3=$ Marina Silva; 4= Alckmin e Alvaro Dias; 5=Daciolo, Amoêdo e Bolsonaro. Nesse caso, o gamma deu um valor de 0,461 , apenas 0,017 acima da categorização de fato usada para nossa comparação.
} 
Quadro 2

Perguntas utilizadas na criação das variáveis que medem as dimensões operacionais da ideologia

\begin{tabular}{|c|c|c|}
\hline $\begin{array}{l}\text { Dimensões } \\
\text { operacionais da } \\
\text { ideologia }\end{array}$ & Código e redação original & Escala original \\
\hline Econômica & $\begin{array}{l}\text { ROS4. O Estado brasileiro deve implementar } \\
\text { políticas firmes para reduzir a desigualdade } \\
\text { de renda entre ricos e pobres. }\end{array}$ & $\begin{array}{l}\text { Se o entrevistado concorda } \\
\text { ou discorda numa escala } \\
\text { de } 1 \text { a } 7\end{array}$ \\
\hline Costumes & $\begin{array}{l}\text { D6. O quanto o(a) sr./sra. aprova ou } \\
\text { desaprova que casais homossexuais tenham } \\
\text { o direito de se casar? }\end{array}$ & $\begin{array}{l}\text { Nível de aprovação medido } \\
\text { por uma escala de } 1 \text { a } 7\end{array}$ \\
\hline $\begin{array}{l}\text { Segurança Pública/ } \\
\text { Ordem }\end{array}$ & $\begin{array}{l}\text { CAPITAL1. O(A) sr./sra. é a favor ou contra a } \\
\text { pena de morte para pessoas que cometeram } \\
\text { assassinato? }\end{array}$ & (1) A favor (2) Contra \\
\hline
\end{tabular}

Fonte: Elaboração própria com base nas questões do Lapop 2019. 


\section{Quadro 3 \\ Controles dos modelos}

\begin{tabular}{|c|c|c|}
\hline Variáveis & Código e redação original & $\begin{array}{c}\text { Categorização } \\
\text { empregada }\end{array}$ \\
\hline Escolaridade & $\begin{array}{l}\text { ED. Qual foi o último ano ou série da escola que o(a) } \\
\text { sr./sra. concluiu com aprovação? } \\
\text { Ano do } \\
\text { secundário, universidade, superior não universitário) }\end{array}$ & Anos de estudo \\
\hline Sexo & Q1. Anotar sem perguntar. & $\begin{array}{l}\text { Mulher como } \\
\text { referência }\end{array}$ \\
\hline Idade & Q2. Quantos anos o(a) sr./sra. tem?____ anos & Anos completos \\
\hline Partido & $\begin{array}{c}\text { VB10. Atualmente o(a) sr./sra. simpatiza com algum } \\
\text { partido político? } \\
\text { (1) Sim [Continue] (2) Não [Vá para BRAANTIP1] } \\
\text { (888888) Não sabe [NÃO LER] [Vá para BRAANTIP1] } \\
\text { (988888) Não responde [NÃO LER] [Vá para BRAANTIP1] } \\
+ \\
\text { VB11. Com qual partido o(a) sr./sra. simpatiza? [NÃO } \\
\text { LER ALTERNATIVAS] } \\
\text { (1501) PT (Partido dos Trabalhadores) } \\
\text { (1502) PMDB (Partido do Movimento Democrático } \\
\text { Brasileiro) } \\
\text { (1503) PSDB (Partido da Social Democracia Brasileira) } \\
\text { (1504) PSB (Partido Socialista Brasileiro) } \\
\text { (1505) DEM (Democratas) } \\
\text { (1506) PC do B (Partido Comunista } \\
\text { do Brasil) } \\
\text { (1507) PPS (Partido Popular Socialista) } \\
\text { (1508) PTB (Partido Trabalhista Brasileiro) } \\
\text { (1509) PSOL (Partido Socialismo e Liberdade) } \\
\text { (1510) PP (Partido Progressista) } \\
\text { (1511) PL (Partido Liberal) } \\
\text { (1512) PV (Partido Verde) } \\
\text { (1513) PDT (Partido Democrático Trabalhista) } \\
\text { (1514) PSL (Partido Social Liberal) } \\
\text { (1515) NOVO (Partido Novo) } \\
\text { (1577) Outro } \\
\text { (88888) Não sabe [NÃO LER] } \\
\text { (98888) Não responde [NÃO LER] } \\
\text { (999999) Não se aplica [NÃO LER] }\end{array}$ & $\begin{array}{c}\text { Sem simpatia } \\
\text { partidária (VB10=2) } \\
\text { como referência } \\
\text { PSL (VB11=1414) } \\
\text { PT }(1501) \\
\text { Outros (VB11=1502, } \\
\text { 1503,1505, 1506, } \\
\text { 1507, 1508,1509, } \\
1510,1511,1512, \\
1513,1515,1577)\end{array}$ \\
\hline
\end{tabular}




\begin{tabular}{|c|c|c|}
\hline Variáveis & Código e redação original & $\begin{array}{c}\text { Categorização } \\
\text { empregada }\end{array}$ \\
\hline $\begin{array}{l}\text { Beneficiário } \\
\text { do Bolsa } \\
\text { Família }\end{array}$ & $\begin{array}{c}\text { CCT1B. Agora falando especificamente sobre o Programa } \\
\text { Bolsa Família, o(a) sr./sra. ou } \\
\text { alguém em sua casa é beneficiário desse programa? } \\
\text { (1) Sim (2) Não } \\
\text { (88888) Não sabe [NÃO LER] } \\
\text { (98888) Não responde [NÃO LER] }\end{array}$ & $\begin{array}{l}\text { Recebe }(1) \text { como } \\
\text { referência } \\
\text { Não Recebe (2) }\end{array}$ \\
\hline Religião & $\begin{array}{c}\text { Q3CN. Qual a sua religião, se tiver? } \\
\text { (01) Católico [Siga] } \\
\text { (02) Protestante Tradicional ou Evangélica não } \\
\text { pentecostal (Batista, Calvinista, Luterano, Metodista, } \\
\text { Presbiteriano, Discípulo de Cristo, Anglicano, Episcopal, } \\
\text { Igreja Cristã Reformada, Igreja Morava, Menonita, } \\
\text { Irmãos em Cristo; Igreja do Nazareno) [Siga] } \\
\text { (03) Outra religião oriental não cristã (Muçulmano, } \\
\text { Budista, Hinduísta, Taoísta, Confuciano, Baha'í) [Siga] } \\
\text { (05) Evangélica pentecostal (Pentecostal, Igreja de Deus, } \\
\text { Assembleias de Deus, Igreja Universal do Reino de Deus, } \\
\text { Igreja Quadrangular, Igreja de Cristo, Congregação } \\
\text { Cristã, Adventista, Adventista de Sétimo Dia, Sara Nossa } \\
\text { Terra, Carismático não Católico, Bola de Neve etc.) [Siga] } \\
\text { (07) Religiões Tradicionais ou nativas (Santeria, } \\
\text { Candomblé, Umbanda, Vodu, Rastafari, religiões maias, } \\
\text { Santo Daime, Esotérica) [Siga] } \\
\text { (1501) Espírita kardecista [Siga] } \\
\text { (04) Nenhuma (Acredita em uma entidade suprema mas } \\
\text { não pertence a nenhuma religião) [Siga] } \\
\text { (11) Agnóstico ou ateu/não acredita em Deus [VÁ PARA } \\
\text { Q5B] } \\
\text { (77) Outra [Siga] } \\
\text { (888888) Não sabe[NÃO LER] [Siga] } \\
\text { (988888) Não responde [NÃO LER] [Siga] }\end{array}$ & $\begin{array}{l}\text { Protestante Tradicional } \\
(02)+\text { Evangélica } \\
\text { Pentecostal }(03), \text { como } \\
\text { "categoria de } \\
\text { referência" } \\
\text { Católico }(01) \text { como } \\
\text { "Católicos" } \\
\\
\text { Demais opções de } \\
\text { resposta como } \\
\text { "Outros". }\end{array}$ \\
\hline
\end{tabular}




\begin{tabular}{|c|c|c|}
\hline Variáveis & Código e redação original & Categorização empregada \\
\hline $\begin{array}{l}\text { Renda familiar } \\
\text { mensal }\end{array}$ & $\begin{array}{c}\text { Q10NEW. Em qual das seguintes } \\
\text { categorias se encontra a renda familiar } \\
\text { mensal dessa } \\
\text { casa, incluindo as remessas do exterior } \\
\text { e a renda de todos os adultos e filhos } \\
\text { que } \\
\text { trabalham? } \\
\text { [Se não entende, perguntar: Quanto } \\
\text { dinheiro entra no total em sua casa } \\
\text { por mês? } \\
\text { (00) Sem renda } \\
\text { (01) Até } R \$ 400 \\
\text { (02) De } R \$ 400 \text { até } R \$ 700 \\
\text { (03) De } R \$ 701 \text { até } R \$ 900 \\
\text { (04) De } R \$ 901 \text { até } R \$ 1.000 \\
\text { (05) De } R \$ 1.001 \text { até } R \$ 1.100 \\
\text { (06) De } R \$ 1.101 \text { até } R \$ 1.200 \\
\text { (07) De } R \$ 1.201 \text { até } R \$ 1.300 \\
\text { (08) De } R \$ 1.301 \text { até } R \$ 1.500 \\
\text { (09) De } R \$ 1.501 \text { até } R \$ 1.700 \\
\text { (10) De } R \$ 1.701 \text { até } R \$ 2.000 \\
\text { (11) De } R \$ 2.001 \text { até } R \$ 2.200 \\
\text { (12) De } R \$ 2.201 \text { até } R \$ 2.500 \\
\text { (13) De } R \$ 2.501 \text { até } R \$ 2.900 \\
\text { (14) De } R \$ 2.901 \text { até } R \$ 3.700 \\
\text { (15) De } R \$ 3.701 \text { até } R \$ 5.600 \\
\text { (16) } M a i s \text { de } R \$ 5.600\end{array}$ & $\begin{array}{c}\text { Fizemos a classificação que mais } \\
\text { permitisse aproximação dos quartis. } \\
\text { Dessa forma: } \\
0-3 \text { Correspondem à categoria de } \\
\text { referência. } \\
\text { E os demais níveis são: } \\
\text { Renda } 2: 4-7 ; \\
\text { Renda } 3: 8-12 ; \\
\text { Renda } 4: 13-16 .\end{array}$ \\
\hline
\end{tabular}

Fonte: Elaboração própria com base nas questões do Lapop 2019.

\section{Abstract}

Context and vote: the impact of the right-wing political forces reorganization on the ideological consistency of the vote in the 2018 elections

This article aims to assess the effect of ideology on Bolsonaro's vote in the 2018 presidential elections. Our argument is that, after a long period of discreet action on Brazilians' political behavior, ideology is again relevant. To explain this change, we adopted a contextualist perspective, according to which the reorganization of the right in the parliament, in the streets and in the media and the offer of an extreme right candidacy in the electoral competition created favorable conditions for the alignment, in the electorate, between ideology and electoral choice in 2018. The analysis reveal that Brazilians are more ideologically oriented and the tests confirm the impact of ideology on presidential choice.

Keywords: ideology; electoral behaviour; 2018 presidential elections

\section{Resumen}

Contexto y voto: el impacto de la reorganización de la derecha en la consistencia ideológica del voto en las elecciones de 2018

Este artículo busca evaluar el efecto de la ideología en el voto del Bolsonaro en las elecciones presidenciales de 2018. Nuestro argumento es que después de un período de acción discreta sobre el comportamiento político de los brasileños, la ideología ha vuelto a ser relevante. Para explicar este cambio, adoptamos una perspectiva contextualista, según la cual la reorganización de la derecha en el parlamento, en las calles y en los medios de comunicación, y la oferta de un candidato de extrema 
derecha en la competición electoral crearon condiciones favorables para el alineamiento, en el electorado, entre la ideología y la elección electoral en 2018. Los análisis revelan que el brasileño está más orientado ideológicamente y las pruebas confirman el impacto de la ideología en la elección presidencial.

Palabras clave: ideología; comportamiento electoral; elecciones 2018

\section{Résumé}

Contexte et vote: l'impact de la réorganisation de la droite sur la cohérence idéologique du vote aux élections de 2018

Cet article cherche à évaluer l'effet de l'idéologie sur le vote de Bolsonaro lors des élections présidentielles de 2018. Notre argument est qu'après une période d'action discrète sur le comportement politique des Brésiliens, I'idéologie a retrouvé sa pertinence. Pour expliquer ce changement, nous avons adopté une perspective contextualiste, selon laquelle la réorganisation de la droite au parlement, dans la rue et dans les médias, et l'offre d'un candidat d'extrême droite dans la compétition électorale ont créé des conditions favorables à l'alignement, dans l'électorat, entre l'idéologie et le choix électoral en 2018. Les analyses révèlent que les Brésiliens sont plus orientés vers l'idéologie et les tests confirment l'impact de l'idéologie sur le choix présidentiel.

Mots clés: idéologie; comportement électoral; élections de 2018

Artigo submetido à publicação em 18 de março de 2020.

Versão final aprovada em 18 de setembro de 2020.

Opinião Pública adota a licença Creative Commons CC-BY. 